\section{Molecular Detection and Prevalence of Citrus Viroids in Texas}

\author{
Madhurababu Kunta, J.V. da Graça, and Mani Skaria ${ }^{1}$ \\ Texas A\&M University-Kingsville Citrus Center, 312 N. International \\ Boulevard, Weslaco, TX 78596
}

Additional index words. citrus, exocortis, cachexia, RT-PCR, biological indexing, Texas budwood certification program

\begin{abstract}
Viroids are graft- or mechanically transmissible agents, disseminated through budding. Biological indexing of commercially important citrus cultivars grown in the Lower Rio Grande Valley of Texas showed that many are infected with citrus viroids. Most of these trees carried more than one viroid. In most cases, the infected trees are asymptomatic carriers because sour orange, the predominant rootstock used in Texas, does not show symptoms of viroid infection. Detection of viroids through biological indexing on sensitive indicator plants followed by sequential polyacrylamide gel electrophoresis (sPAGE) is the gold standard but is time-consuming and requires plants to be kept at optimum conditions. A conditional use of reverse transcriptase-polymerase chain reaction (RT-PCR) provides an efficient and alternative detection of viroids for use in the Texas virus-free citrus budwood certification program. RT-PCR could be useful in Texas to help expedite the evaluation for the presence of viroids before conducting the final biologic indexing. Using RT-PCR, we could detect, clone, and sequence full-length viroids of Citrus exocortis viroid (CEVd), Hop stunt viroid (HSVd) (both cachexia and noncachexia variants), Citrus viroid-III (Citrus dwarfing viroid), and Citrus viroid-IV (Citrus bark cracking viroid) from a collection of viroid-inoculated grapefruit plants. The source plants were previously shown to be viroid-infected by biological indexing on Etrog citron plants. Based on our results, RT-PCR can be a conditional substitute for biological indexing of mother trees in foundation blocks and shoot tip-grafted trees in the virus-free budwood program. A positive RT-PCR result has a serendipitous value because those trees can be discarded from the pool before expensive biological indexing.
\end{abstract}

Viroids are small infectious agents of single-stranded, unencapsidated, nontranslated, circular RNA with self-complementary sequences (Flores et al., 1998). Citrus viroids have been classified into distinct groups based on their biological and physical properties: Citrus exocortis viroid (CEVd), Citrus bent leaf viroid (CBLVd), Hop stunt viroid (HSVd), Citrus dwarfing viroid (CVd-III), and Citrus bark cracking viroid (CVd-IV). Recently, a new citrus viroid species, tentatively named Citrus viroid OS (CVd-OS), was reported (Ito et al., 2001). These viroids have small genomes ranging from 284 to 375 nucleotides (Duran-Vila et al., 1988). In citrus, viroids cause two economically important diseases, exocortis and cachexia (xyloporosis) (Roistacher, 1991). Other citrus diseases associated with viroids include wood pitting (Fernandez-Valiela et al., 1965), gum pocket, and gummy pitting in trifoliate orange (Schwarz and McClean, 1969); yellow corky vein and gummy bark in sweet orange (Reddy et al., 1974); and kassala disease in grapefruit (Bové, 1995). Exocortis was first described in 1948 as a bark-shelling or scaling disorder in trees

Received for publication 9 Nov. 2006. Accepted for publication $10 \mathrm{Feb} .2007$.

We thank Dr. Eliezer Louzada for helpful technical advice in RT-PCR work.

${ }^{1}$ To whom reprint requests should be addressed; e-mail MSkaria@ag.tamu.edu strated to be graft-transmissible (Benton et al., 1949, 1950) and incited by CEVd (Semancik and Weathers, 1972). Similar disorders were also reported as scaly butt of trifoliate orange in Australia (Benton et al., 1949) and in Rangpur lime (Citrus limonia Osbeck) in Brazil (Moreira, 1955, 1959). HSVd variants include CVd-IIa, CVd-IIb, and CVd-IIc (Foissac and Duran-Vila, 2000; Palacio-Bielsa et al., 2004; Reanwarakorn and Semancik, 1999a, 1999b; Semancik et al., 1988a, 1988b). CVd-IIb was shown to be the causal agent of cachexia disease, which induces severe gumming, stem pitting, and discoloration of the indicator plant, Parson's Special mandarin (PSL) (DuranVila et al., 1988; Semancik et al., 1988a, 1988b). It was also demonstrated that CVdIIb or CVdIIc can cause cachexia symptoms on Orlando tangelo and PSL (Reanwarakorn and Semancik, 1999a, 1999b).

Generally, old-line red grapefruit (C. paradisi Macf.) trees in Texas carried at least cachexia, and most sweet orange (C. sinensis) trees carried both cachexia and exocortis viroids (Olson, 1952; Olson and Shull, 1955; Olson et al., 1958; Sleeth 1959). Moreover, susceptibility of 25 cultivars of mandarin $(C$. reticulata $\mathrm{L}$.) and mandarin hybrid rootstocks to cachexia and its occurrence in commercial red grapefruit prompted intensive rootstock studies through viroid indexing in Texas (Olson, 1954). It was also shown that 12-year-old, viroid-free Valencia orange trees on Cleopatra mandarin, rough lemon, and sour orange rootstocks generally grew faster and yielded more compared with trees infected with exocortis and cachexia (Olson and Shull, 1962). Also, inoculation of Star Ruby grapefruit on Troyer citrange $[P$. trifoliata (L.) Raf. $\times$ C. sinensis (L.) Osbeck] rootstock with a severe strain of exocortis reduced trunk diameter and canopy volume (Timmer, 1978). Viroid indexing studies on Etrog citron showed symptoms resembling those induced by $\mathrm{CEVd}, \mathrm{CVd}-\mathrm{II}$, CVd-III, or CVd-IV (Miao et al., 1996). They observed a few plants showed petiole wrinkle or discoloration or tip browning of the leaves, which may be associated with CVd-II. Identification of citrus viroids based only on the symptomatology in Etrog citron (C. medica L.) has many disadvantages because the symptom expression requires a long waiting period and can be affected by environmental conditions.

The objectives of this study were to evaluate the reverse transcriptase-polymerase chain reaction (RT-PCR) technique as a quick method to screen a large number of trees for the presence of viroids in the virustested budwood program to improve the budwood program and help expedite introduction of new germplasm into the program and to identify which viroids occur in Texas. Biological indexing, the gold standard in virus-free citrus production, is expensive, timeconsuming but a necessity (Skaria et al., 1997). However, there may be potential for a conditional replacement if a rapid, sensitive, and reliable technique is available as is used in other programs.

\section{Materials and Methods}

Plant materials. Viroid-infected Rio Red grapefruit (C. paradisi Macf.) plants on sour orange rootstock were selected based on results from previous biological indexing (Miao et al., 1996). All original viroid source plants were initially indexed on Etrog citron 861-S-1. They produced symptoms of leaf epinasty, plant stunting, leaf drooping, leaf browning, petiole necrosis, petiole twisting, and petiole wrinkle. Sets of five Rio Red grapefruit trees were inoculated with different viroid sources from commercial grapefruit and orange cultivars in the field and maintained at the Texas A\&M UniversityKingsville Citrus Center. One tree from each source group was selected for analysis. Healthy, viroid-free plants were used as controls. Bark tissue from mature stems and leaves of these plants were used for nucleic acid extraction. Very tender shoot tips or mature leaves were avoided because they were reported to be unsuitable sources for CEVd and CVd-II detection (Garnsey et al., 2002). Tissues collected were either used immediately for nucleic acid extractions or stored at $-20{ }^{\circ} \mathrm{C}$ until extracted. The test plants were harvested during the summer 
Table 1. The oligonucleotide primer pairs used for various citrus viroids in reverse transcriptase-polymerase chain reaction and polymerase chain reaction.

\begin{tabular}{|c|c|c|c|}
\hline Viroid & Name & Sequence & Target (product size) \\
\hline \multirow{2}{*}{$\overline{\mathrm{CEVd}}$} & CEVd-F1 ${ }^{z}$ & 5'-GGAAACCTGGAGGAAGTCG-3' & \\
\hline & CEVd-H ${ }^{\mathrm{y}}$ & 5'-ATCCCCGGGGAACCTGGAGGAAG-3' & \\
\hline \multirow[t]{3}{*}{ HSVd } & HSVd-RT & 5'-GTGTTGCCCCGGGGCTCCTTTCTCTGG-3' & $299 \mathrm{bp}$ \\
\hline & HSVd-R $1^{z}$ & 5'-GGGGCTCCTTTCTCAGGTAAGTC-3' & \\
\hline & HSVd-F1 ${ }^{z}$ & 5'-GGGGCAACTCTTCTCAGAATCC-3' & \\
\hline \multirow[t]{3}{*}{ CBLVd } & CBLVd-RT $^{2}$ & 5'-GCTGACGAGCCTTCGTCGACGACGACC-3' & \\
\hline & CBLVD-R1 ${ }^{z}$ & 5'-TTCGTCGACGACGACCAGTC-3' & $327 \mathrm{bp}$ \\
\hline & ${\mathrm{CBLVd}-\mathrm{F} 1^{\mathrm{z}}}$ & 5'-GGCTCGTCAGCTGCGGAGGT-3' & \\
\hline \multirow[t]{4}{*}{ CVd-III } & CVd-III-RT ${ }^{2}$ & 5' -CCAACTTAGCTGCCTTCGTCGACGACG-3' & \\
\hline & CVd-III-R1 ${ }^{z}$ & 5'-TTCGTCGACGACGACAGGTA-3' & $294 \mathrm{bp}$ \\
\hline & CVd-III-F1 ${ }^{z}$ & 5'-GGCAGCTAAGTTGGTGACGC-3' & \\
\hline & CVdIII-H ${ }^{y}$ & 5'-CTCCGCTAGTCGGAAAGACTCCGC-3' & \\
\hline CVd-OS & $\mathrm{CB} 3-\mathrm{CP}^{\mathrm{x}}$ & 5'-CGTCGACGAAGGCATGTGAGCT-3' & \\
\hline
\end{tabular}

${ }^{2}$ Primers described previously by Bernad and Duran-Vila (2006).

yPrimers defined by Garnsey et al. (2002).

${ }^{x}$ Primers defined by Ito et al. (2001).

months when growth conditions are optimum for viroids (Roistacher, 1991).

Preparation of nucleic acid extracts with viroid RNA targets. The method used for extraction of dsRNAs from plant tissue was an adaptation of the sodium dodecyl sulfatepotassium acetate (SDS-KAc) method (DePaulo and Powell, 1995). Tissue (0.25 g) was pulverized with a mortar and pestle in the presence of liquid nitrogen and the tissue was immediately transferred to a $2.0-\mathrm{mL}$ centrifuge tube. Thawing of the pulverized tissue was avoided. To this powder, $750 \mu \mathrm{L}$ of the extraction buffer $(0.1 \mathrm{~m}$ Tris, $\mathrm{pH} 8.0$, $50 \mathrm{~mm}$ EDTA, $500 \mathrm{~mm} \mathrm{NaCl}$, and $10 \mathrm{~mm}$ 2-mercaptoethanol) and $100 \mu \mathrm{L}$ of $10 \%$ SDS were added. The preparation was vortexed and incubated for $30 \mathrm{~min}$ at $65^{\circ} \mathrm{C}, 500 \mu \mathrm{L}$ of 5 м KAc was added, mixed thoroughly, and incubated on ice for $20 \mathrm{~min}$. After centrifugation $(\approx 17,000 \times g)$, the supernatant was transferred to a clean 2.0 -mL centrifuge tube. To the supernatant, 0.1 vol of sodium acetate $(\mathrm{NaOAc})$ and $3 \mathrm{vol}$ of ethanol were added, mixed, and incubated for $5 \mathrm{~h}$ at $-20{ }^{\circ} \mathrm{C}$. The nucleic acids were recovered as a pellet by centrifugation at $9000 \times g$ for $20 \mathrm{~min}$, airdried, resuspended in $100 \mu \mathrm{L}$ sterile water, and stored at $-70{ }^{\circ} \mathrm{C}$.

Reverse transcriptase-polymerase chain reaction. First-strand viroid cDNA was synthesized using $15 \mathrm{U}$ of ThermoScript Reverse Transcriptase (Invitrogen, Carlsbad, Calif) according to the manufacturer's instructions. Reverse transcription of $0.5 \mu \mathrm{g}$ of total RNA was performed in a $20-\mu \mathrm{L}$ reaction including $4 \mu \mathrm{L}$ of $5 \times$ buffer $(250 \mathrm{~mm}$ Tris acetate, 375 $\mathrm{mm}$ potassium acetate, $40 \mathrm{~mm}$ magnesium acetate), $200 \mu \mathrm{M}$ of each dNTPs, $1 \mu \mathrm{M}$ of reverse specific primer (Table 1), $40 \mathrm{U}$ of RNase Out, $10 \mathrm{~mm}$ DTT, and $15 \mathrm{U}$ of ThermoScript Reverse Transcriptase. The reaction was incubated at $60{ }^{\circ} \mathrm{C}$ for $1 \mathrm{~h}$ and the reverse transcriptase was inactivated by heating the reaction mixture to $85{ }^{\circ} \mathrm{C}$ for 5 min followed by rapid cooling on ice. Second-strand cDNA synthesis and subsequent polymerase chain reaction (PCR) amplification were performed on $1.5 \mu \mathrm{L}$ of first-strand cDNA mixture using $1 \mathrm{U}$ of HotStarTaq DNA polymerase (Qiagen, Valencia, Calif.) in a $25-\mu \mathrm{L}$ reaction including $2.5 \mu \mathrm{L}$ of $10 \times$ PCR buffer [Tris. HCl, $\mathrm{KCl},\left(\mathrm{NH}_{4}\right)_{2} \mathrm{SO}_{4}, 15 \mathrm{~mm} \mathrm{MgCl} 2 ; \mathrm{pH}$ 8.7], $0.2 \mathrm{~mm}$ each of dNTPs, and $0.25 \mu \mathrm{M}$ each of selected forward and reverse primers (Table 1). The PCR conditions were optimized (Bernad and Duran-Vila, 2006) as $15 \mathrm{~min}$ at $95{ }^{\circ} \mathrm{C}$ followed by 35 cycles of $30 \mathrm{~s}$ at $94^{\circ} \mathrm{C}, 30 \mathrm{~s}$ at $60{ }^{\circ} \mathrm{C}, 1 \mathrm{~min}$ at $72{ }^{\circ} \mathrm{C}$, and a final extension of $10 \mathrm{~min}$ at $72^{\circ} \mathrm{C}$. The PCR parameters for CVd-OS detection were the same except that the annealing temperature was $55^{\circ} \mathrm{C}$. The PCR products were run on $2 \%$ agarose gels in Tris-Acetate-EDTA buffer, stained with ethidium bromide, and visualized under ultraviolet light to confirm the synthesis of amplicons of expected size.
Sequencing and analysis of viroid $c D N A$. Full-length viroid amplicons of expected size were gel-purified using QIAquick Gel Extraction Kit (Qiagen) and cloned into PCR 4-TOPO vector (Invitrogen). Plasmids from transformed cells were purified by Qiaprep Miniprep kit (Qiagen) and sequenced at MWG-Biotech DNA sequencing facility (MWG-Biotech, High Point, N.C.). The DNA sequence was compared for homology to sequences deposited at the GenBank database.

\section{Results and Discussion}

Results from RT-PCR assay of test plants are shown in Table 2, Figure 1, and Figure 2. The full-length cDNAs of CEVd, HSVd, CVd-III, and CVd-IV consisting of $370 \mathrm{bp}$, 303 bp, 295 bp, and 284 bp, respectively, were sequenced. Because source plant $12 \mathrm{E}$ gave negative results (Fig. 1), the other four trees in the group inoculated from the same field source (a, b, c, d) were analyzed by RTPCR and were found to contain cachexia variants of HSVd (Table 2). It is therefore

Table 2. Results of reverse transcriptase-polymerase chain reaction assay of viroid-infected grapefruit plants.

\begin{tabular}{lcl}
\hline Field source of viroids & Tested plants & \multicolumn{1}{c}{ Viroid presence } \\
\hline $\begin{array}{l}\text { Henderson grapefruit G } \\
\text { Valencia orange A }\end{array}$ & 1A & CEVd, HSVd (cachexia variants of HSVd), and CVd-III \\
N-33 Navel orange A & 2E & CEVd, HSVd (cachexia variants of HSVd), and CVd-III \\
N-33 Navel orange B & 4D & CEVd, HSVd (cachexia variants of HSVd), and CVd-III \\
CEVd, HSVd (noncachexia variants of HSVd), \\
and CVd-III \\
Everhard Navel orange C & 6E & $\begin{array}{l}\text { CEVd, HSVd (cachexia variants of HSVd), CVd-III, } \\
\text { and CVd-IV }\end{array}$ \\
$\begin{array}{l}\text { Marrs orange E } \\
\text { Marrs orange E }\end{array}$ & 12E & $\begin{array}{l}\text { Negative } \\
\text { HSVd (cachexia variants of HSVd) }\end{array}$ \\
$\begin{array}{l}\text { Henderson grapefruit 1 } \\
\text { Control, not inoculated }\end{array}$ & CA, B, and D & CEVd, HSVd (cachexia variants of HSVd), and CVd-III \\
Rio red grapefruit & 44D & Negative \\
\hline
\end{tabular}


possible that $12 \mathrm{E}$ was not successfully infected during the original inoculation. PCR amplification using strain-specific primers of HSVd (Table 1) resulted in a $220 \mathrm{bp}$ amplicon only for noncachexia variants and 279 bp amplicon only for cachexia variants (Fig. 3). Homology searches for these nucleotide sequences at the GenBank database showed $98 \%$ to $100 \%$ identities to previously established, respective, viroid sequences. A similarity search for full-length cDNA of CVd-III showed $100 \%$ identity to a citrus dwarfing viroid from Cuba and a citrus dwarfing viroid, CVd-IIIa, from Australia (accession nos. AJ630358 and S75465). Also, cDNA nucleotide sequence of CVdIV showed $100 \%$ identity with CVd-IV sequences reported from Cuba (accession no. AJ630360) and Japan (accession no. AB054633). Alignment of CEVd, HSVd, cachexia variants of HSVd, CVd-III, and CVd-IV cDNA nucleotide sequences as described by Corpet (1988) revealed some conserved regions.

Studies on mechanical transmission of cachexia and exocortis showed that these viroids can be transmitted by slashing with a knife blade (Garnsey and Jones, 1967; Garnsey and Whidden, 1973; Roistacher, 1983). In a greenhouse transmission study, it was also reported that CBLVd and all strains of HSVd, CVd-III, and CVd-IV were mechanically transmissible by a single slash (Barbosa et al., 2005). Transmission of viroids in trees growing in the field was also demonstrated with different transmission efficiencies in different host plants (Barbosa et al., 2002). Thus, there is a great possibility for spreading of these viroids by propagation of infected budwood and contaminated pruning tools (Roistacher, 1991). The Texas citrus budwood certification program was initiated to produce virus-free budwood regulated by the Texas Department of Agriculture (Skaria et al., 1996, 1997). Budwood sources were subjected to biological indexing to test for the presence of viroids and viruses, shoot tipgrafted to produce virus-and viroid-free budwood sources, reindexed, and planted in a foundation block (Skaria et al., 1996). Budwood from these plants is used to produce increased block trees that supply budwood to nurseries. There are over 80 varieties in the foundation block and $\approx 280,000$ buds have been supplied to nurseries since 1998 (Kahlke et al., 2005). For viroids, biologic indexing is being performed every 4 to 5 years (Kahlke et al., 2005). Citrus viroids can be detected by indexing on sensitive indicators such as Etrog citron for exocortis (Calavan et al., 1964) and PSL for cachexia (Roistacher et al., 1973; Vogel and Bové, 1976) followed by sequential polyacrylamide gel electrophoresis (sPAGE). This is a standard, sensitive method but there are some disadvantages, for example, biological indexing on Etrog citron requires 3 to 6 months and indexing on PSL for cachexia requires at least 1 year. Maintaining index plants at 28 to $30{ }^{\circ} \mathrm{C}$ for several months and requiring expertise in diagnosis of symptoms make this
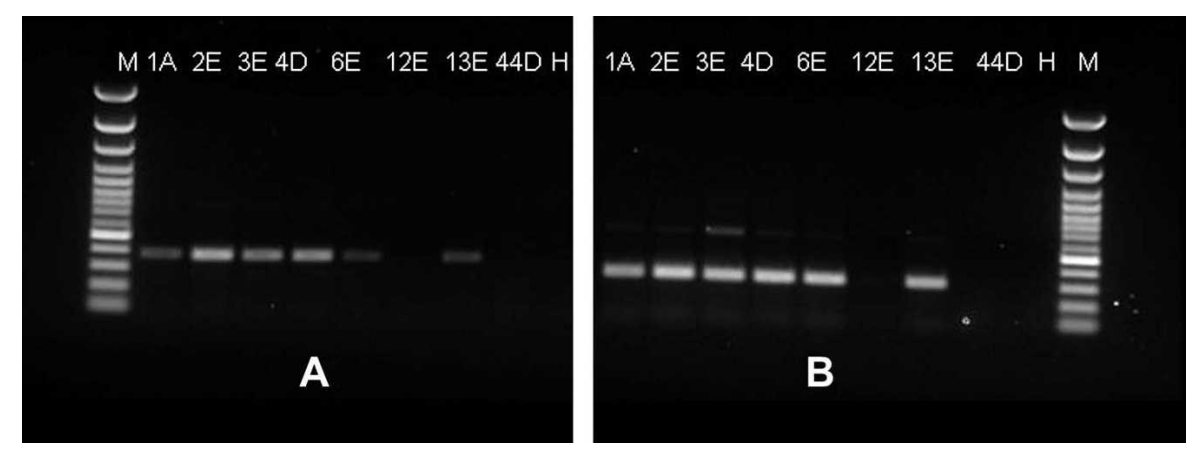

Fig. 1. Agarose gel showing reverse transcriptase-polymerase chain reaction products amplified with specific primers for (A) CEVd and (B) HSVd from viroid-infected grapefruit samples. 44D = noninoculated control; $\mathrm{H}=$ healthy $(-) ; \mathrm{M}=100$ bp DNA ladder.
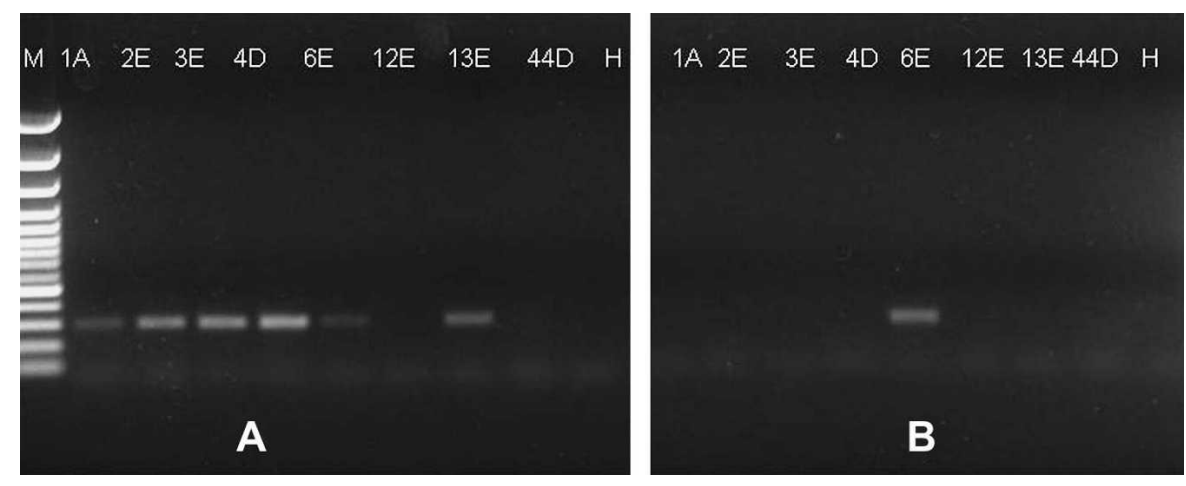

Fig. 2. Agarose gel showing reverse transcriptase-polymerase chain reaction products amplified with specific primers for (A) CVd-III and (B) CVd-IV from viroid-infected grapefruit samples. $\mathrm{H}=$ healthy $(-) ; 44 \mathrm{D}=$ noninoculated control; $\mathrm{M}=100 \mathrm{bp}$ DNA ladder.
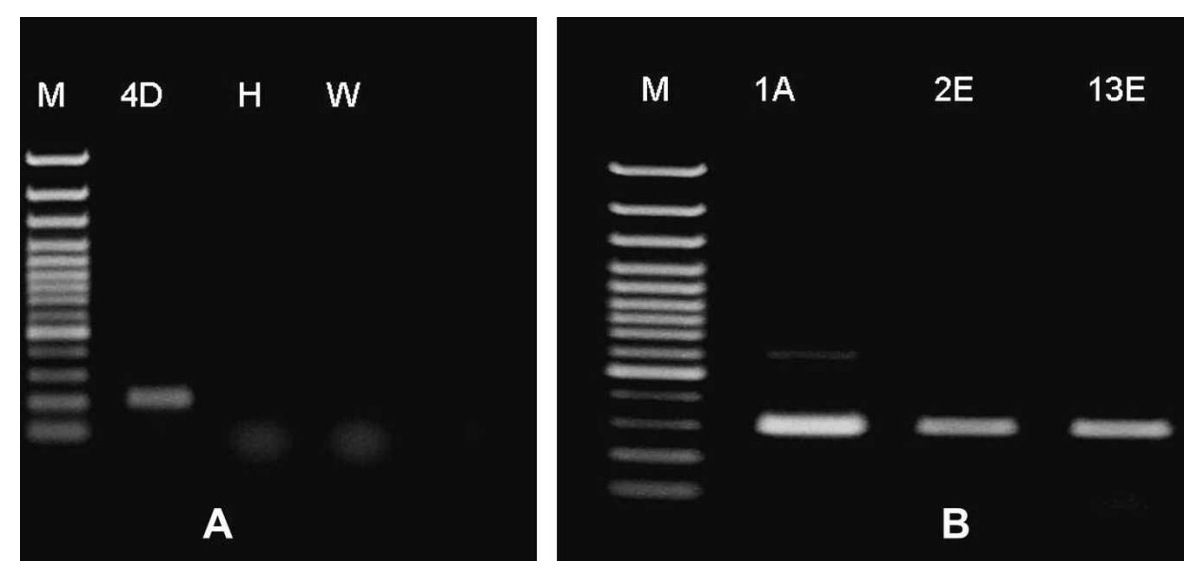

Fig. 3. Agarose gel electrophoresis of reverse transcriptase-polymerase chain reaction products amplified with specific primers for noncachexia variants of (A) HSVd and (B) cachexia variants from viroidinfected grapefruit samples. $\mathrm{H}=$ healthy $(-)$; $\mathrm{W}=$ water $(-)$ controls; $\mathrm{M}=100$ bp DNA ladder.

an expensive process. Conversely, RT-PCR became a useful and popular method for practical detection of viroids because of its simplicity and sensitivity when compared with conventional bioassays and sPAGE. However, presence of inhibitors in the plants such as polyphenolics, polysaccharides, and endogenous ribonucleases drastically decreases the detection sensitivity of the RT-PCR reactions (Gibb and Padovan, 1994; Singh et al., 2002). Moreover, detection of viroids through RT-PCR is limited by inefficient synthesis of viroid full-length cDNA during the PCR reaction (Bernad and Duran-Vila, 2006). Additionally, it was reported that some sequence variants of CVd-III may escape the detection by RTPCR; if proper sequence primers are not used (Garnsey et al., 2002). Highly purified viroid preparations, achieving viroid full-length cDNA by optimizing amplification conditions and careful selection of primers, are prerequisite in using RT-PCR detection of viroids (Ragozzino et al., 2004). Use of the 
RT-PCR method in detection and characterization of citrus viroids is well established (Bernad and Duran-Vila, 2006; Ito et al., 2002; Sieburth et al., 2002).

This is the first report of the detection and characterization of citrus viroids by RT-PCR in Texas confirming the presence of CEVd, HSVd, and CVd-III commonly in all the trees. CVd-IV was found in only one tree in our study. CVd-IV was previously reported from California (Duran-Vila et al., 1988), Israel (Puchta et al., 1991), Japan (Hataya, 1997), Turkey (Önelge et al., 2000), Cuba (Velázquez et al., 2002), Tunisia (Najar et al., 2002), and Italy (Malfitano et al., 2005). CVd-IV was not detected in Uruguay (Pagliano et al., 2000) or Mexico (Almeyda-León et al., 2007). CBLVd and CVd-OS (Ito et al., 2001) were not detected in the sampled trees. RTPCR is highly useful in routine diagnosis of citrus viroids and it can selectively replace some of the need for biological indexing of RT-PCR-positive trees in the citrus budwood program. In the virus-free budwood program, all test plants from the foundation block or shoot tip grafting with a positive RT-PCR test can be discarded from the budwood program without an expensive biological indexing with substantial saving of money and time.

\section{Literature Cited}

Almeyda-León, M.A., M.A. Rocha-Peña, M.M. Iracheta-Cárdenas, F. Orona-Castro, and C.J. Kahlke. 2007. A simple method for the multiple detection of citrus viroids. Agrociencia 41:87-93.

Barbosa, C.J., J.A. Pina, L. Navarro, and N. Duran-Vila. 2002. Replication/accumulation and symptom expression of citrus viroids on some species of citrus and related genera, p. 264-271. In: N. Duran-Vila, R.G. Milne, and J.V. da Graça (eds.). Proc. 15th Conf. Intl. Org. Citrus Virol., IOCV, Riverside, Calif.

Barbosa, C.J., J.A. Pina, J. Perez-Panades, L. Bernad, P. Serra, L. Navarro, and N. DuranVila. 2005. Mechanical transmission of citrus viroids. Plant Dis. 89:749-754.

Benton, R.J., F.T. Bowman, L. Fraser, and R.G. Kebby. 1949. Selection of citrus budwood to control scaly butt in trifoliata rootstock. Agr. Gaz. N.S.W. 60:31-34.

Benton, R.J., F.T. Bowman, L. Fraser, and R.G. Kebby. 1950. Stunting and scaly butt associated with Poncirus trifoliata rootstock. N.S.W. Dept. Agr. Sci. Bul. 70:1-20.

Bernad, L. and N. Duran-Vila. 2006. A novel approach for detection and characterization of citrus viroids. Mol. Cell. Probes 20:105-113.

Bové, J.M. 1995. Virus and virus-like diseases of citrus in the Near East region. FAO, Rome, Italy.

Calavan, E.C., E.F. Frolich, J.B. Carpenter, C.N. Roistacher, and D.W. Christiansen. 1964. Rapid indexing for exocortis of citrus. Phytopathology 54:1359-1362.

Corpet, F. 1988. Multiple sequence alignment with hierarchical clustering. Nucleic Acids Res. 16:10881-10890.

DePaulo, J.J. and C.A. Powell. 1995. Extraction of double-stranded RNA from plant tissue without the use of organic solvents. Plant Dis. 79:246248.

Duran-Vila, N., C.N. Roistacher, R. RiveraBustamante, and J.S. Semancik. 1988. A definition of citrus viroid groups and their relationship to the exocortis disease. J. Gen. Virol. 69:3069-3080.

Fawcett, H.S. and L.J. Klotz. 1948. Exocortis on trifoliate orange. Citrus Leaves 28:8.

Fernandez-Valiela, M.V., C. Fortugno, and F. Corizzi. 1965. Incidence of bud-union crease in citrus trees grafted on trifoliata rootstock in the Delta del Parana and San Pedro areas of Argentina, p. 182-186. In: W.C. Price (ed.). Proc. 3rd Conf. Intl. Org. Citrus Virol., IOCV, Riverside, Calif.

Flores, R., J.W. Randles, M. Bar-Joseph, and T.O. Diener. 1998. A proposed scheme for viroid classification and nomenclature. Arch. Virol. 143:623-629.

Foissac, X. and N. Duran-Vila. 2000. Characterization of two citrus apscaviroids isolated in Spain. Arch. Virol. 145:1975-1983.

Garnsey, S.M. and J.W. Jones. 1967. Mechanical transmission of exocortis virus with contaminated budding tools. Plant Dis. Rpt. 51:410413.

Garnsey, S.M. and R. Whidden. 1973. Efficiency of mechanical inoculation procedures for citrus exocortis viroids. Plant Dis. Rpt. 57:886-889.

Garnsey, S.M., D.L. Zies, M. Irey, P.J. Sieburth, J.S. Semancik, L. Levy, and M.E. Hilf. 2002. Practical field detection of citrus viroids in Florida by RT-PCR, p. 219-229. In: N Duran-Vila, R.G. Milne, and J.V. da Graça (eds.). Proc. 15th Conf. Intl. Org. Citrus Virol., IOCV, Riverside, Calif.

Gibb, K. and A. Padovan. 1994. A DNA extraction method that allows reliable PCR amplification of MLO DNA from difficult plant host species. PCR Methods Appl. 4:56-58.

Hataya, T. 1997. Characteristics and detection methods of viroids detected from citrus in Japan. Shokubutsu Buick. 51:163-167.

Ito, T., H. Ieki, and K. Ozaki. 2002. Simultaneous detection of six citrus viroids and Apple stem grooving virus from citrus plants by multiplex reverse transcription polymerase chain reaction. J. Virol. Methods 106:235-239.

Ito, T., H. Ieki, K. Ozaki, and T. Ito. 2001. Characterization of a new citrus viroid species tentatively termed citrus viroid OS*. Arch. Virol. 146:975-982.

Kahlke, C.J., J.W. Watson, N. Solís-Gracia, M. Skaria, and J.V. da Graça. 2005. The Texas citrus budwood certification program, p. 480 483. In: M.E. Hilf, N. Duran-Vila, and M.A. Rocha-Peña (eds.). Proc. 16th Conf. Intl. Org. Citrus Virol, IOCV, Riverside, Calif.

Malfitano, M., M. Barone, D. Alioto, and N. DuranVila. 2005. Indexing of viroids in citrus orchards of Campania, southern Italy. J. Plant Pathol. 87:115-121.

Miao, H., M. Skaria, and N. Solís-Gracia. 1996. Detection of viroids in five commercial citrus cultivars in Texas, p. 360-362. In: J.V. da Graça, P. Moreno, and R.K. Yokomi (eds.) Proc. 13th Conf. Intl. Org. Citrus Virol., IOCV, Riverside, Calif.

Moreira, S. 1955. Sintomas de "exocortis" em limoneiro cravo. Bragantia 14:19-21.

Moreira, S. 1959. Rangpur lime disease and its relationship to exocortis, p. 135-140. In: J.M. Wallace (ed.). Citrus virus diseases. Univ. of Calif. Div Agr. Sci., Berkeley.

Najar, A., N. Duran-Vila, and M.L. Caruana. 2002. Identification of viroids in citrus orchards in Tunisia, p. 398-400. In: Duran-Vila, N., R.G. Milne, and J.V. da Graça (eds.). Proc. 15th Conf. Intl. Org. Citrus Virol., IOCV, Riverside, Calif.

Olson, E.O. 1952. Investigations of citrus rootstock diseases in Texas. Proc. Rio Grande Valley Hort. Inst. 6:46-50.
Olson, E.O. 1954. Some bark and bud union disorders of mandarin and mandarin-hybrid rootstocks in Texas citrus plantings. Proc. Amer. Soc. Hort. Sci. 63:131-136.

Olson, E.O. and A.V. Shull. 1955. Red grapefruit strains as symptomless carriers of the casual agent of cachexia, a bud transmitted disease. Proc. Rio Grande Valley Hort. Inst. 9:46-50.

Olson, E.O. and A.V. Shull. 1962. Size and yield of 12-year-old Valencia orange trees on various rootstocks in presence or absence of exocortis and xyloporosis viruses. J. Rio Grande Valley Hort. Soc. 16:40-43.

Olson, E.O., B. Sleeth, and A.V. Shull. 1958. Prevalence of viruses causing xyloporosis (cachexia) and exocortis (Rangpur lime disease) in apparently healthy citrus trees. J. Rio Grande Valley Hort. Soc. 12:35-43.

Önelge, N., U. Kersting, Y. Guang, M. Bar-Joseph, and O. Bozan. 2000. Nucleotide sequence of citrus viroids CVd-IIIa and CVd-IV obtained from dwarfed Meyer lemon trees grafted on sour orange. J. Plant Dis. Prot. 107:387-391.

Pagliano, G., M. Peyrou, R. Del Campo, L. Orlando, A. Gravina, R. Wettstein, and M. Francis. 2000. Detection and characterization of citrus viroids in Uruguay, p. 282-288. In: J.V. da Graça, R.F. Lee, and R.K. Yokomi (eds.). Proc. 14th Conf. Intl. Org. Citrus Virol, IOCV, Riverside, Calif.

Palacio-Bielsa, A., J. Romero-Durbán, and N. Duran-Vila. 2004. Characterization of citrus HSVd isolates. Arch. Virol. 149:537-552.

Puchta, H., K. Ramm, R. Luckinger, R. Hadas, M. Bar-Joseph, and H.L. Sänger. 1991. Primary and secondary structure of citrus viroid IV (CVd IV), a new chimeric viroid present in dwarfed grapefruit in Israel. Nucleic Acids Res. 19:6640.

Ragozzino, E., F. Faggioli, and M. Barba. 2004. Development of a one tube-one step RT-PCR protocol for the detection of seven viroids in four genera: Apscaviroid, Hostuviroid, Pelamoviroid, and Pospiviroid. J. Virol. Methods 121:25-29.

Reanwarakorn, K. and J.S. Semancik. 1999a. Discrimination of cachexia disease agents among citrus variants of hop stunt viroid. Ann. Appl. Biol. 135:481-487.

Reanwarakorn, K. and J.S. Semancik. 1999b. Correlation of hop stunt viroid variants to cachexia and xyloporosis diseases of citrus. Phytopathology 89:568-574.

Reddy, G.S., V. Dakshinamurti, and V.R.K. Reddy. 1974. Yellow corky-vein: First report of a new graft-transmissible disorder of Sathgudi in Andhra Pradesh. Indian Phytopathol. 27: $82-84$.

Roistacher, C.N. 1983. Cachexia disease: Virus or viroid. Citrograph 68:111-113.

Roistacher, C.N. 1991. Graft-transmissible diseases of citrus: Handbook for detection and diagnosis. FAO, Rome, Italy.

Roistacher, C.N., R.L. Blue, and E.C. Calavan. 1973. A new test for citrus cachexia. Citrograph 58:261-262.

Schwarz, R.E. and A.P.D. McClean. 1969. Gumpocket, a new virus-like disease of Poncirus trifoliata. Plant Dis. Rpt. 53:336-339.

Semancik, J.S., C.N. Roistacher, and N. DuranVila. 1988a. A new viroid is the causal agent of the citrus cachexia disease, p. 125-135. In: L.W. Timmer, S.M. Garnsey, and L. Navarro (eds.). Proc. 10th Conf. Intl. Org. Citrus Virol., IOCV, Riverside, Calif.

Semancik, J.S., C.N. Roistacher, R. RiveraBustamante, and N. Duran-Vila. 1988b. Citrus cachexia viroid, a new viroid of citrus: 
Relationship to viroids of the exocortis disease complex. J. Gen. Virol. 69:3059-3068.

Semancik, J.S. and L.G. Weathers. 1972. Exocortis virus: An infectious free-nucleic acid plant virus with unusual properties. Virology 46: 456-466.

Sieburth, P.J., M. Irey, S.M. Garnsey, and R.A. Owens. 2002. The use of RT-PCR in the Florida citrus viroid indexing program, p. 230-239. In: N. Duran-Vila, R.G. Milne, and J.V. da Graça (eds.). Proc. 15th Conf. Intl. Org. Citrus Virol., IOCV, Riverside, Calif.

Singh, R.P., X. Nie, M. Singh, R. Coffin, and P. Duplessis. 2002. Sodium sulphite inhibition of potato and cherry polyphenolics in nucleic acid extraction for virus detection by RT-PCR. J. Virol. Methods 99:123-131.

Skaria, M., J. Baker, C. Kahlke, N. Solís-Gracia, C.N. Roistacher, and J.V. da Graça. 1996. A virus-free citrus budwood program for Texas. Proc. Intl. Soc. Citricult. 1:366-368.

Skaria, M., C. Kahlke, N. Solís-Gracia, and R. Prewett. 1997. Virus-free citrus budwood production and tristeza management program in Texas through industry partnership. Subtrop. Plant Sci. 49:1-7.

Sleeth, B. 1959. The citrus budwood certification program in Texas, p. 233-236. In: J.M. Wallace (ed.). Citrus virus diseases. Univ. of Calif. Press, Riverside.
Timmer, L.W. 1978. Effect of exocortis infection on the performance of Star Ruby grapefruit on sour orange and troyer citrange rootstocks. J. Rio Grande Valley Hort. Soc. 32:29-33.

Velázquez, M., M.S.R. Peréz, J.M. Peréz, D. Rodriguez, and N. Duran-Vila. 2002. Biological and molecular characterization of two isolates of citrus viroids recovered from Cuban plantations, p. 258-263. In: N. Duran-Vila, R.G. Milne, and J.V. da Graça (eds.). Proc. 15th Conf. Intl. Org. Citrus Virol., IOCV, Riverside, Calif.

Vogel, R. and J.M. Bové. 1976. La nouvelle technique d'indexation de la cachexie-xyloporose: Son utilisation en Corse. Fruits 31:93-96. 